\title{
Ch. II. Of the originall and first greatnesse of the Persians
}

\section{Ch. III. Of Cyrvs}

Ch. IV. The estate of things from the death of Cyrvs to the Raigne of Darivs

Ch. V. Of Darivs the Sonne of Hyspaspes

\section{Ch. VI. Of Xerxes $^{\mathrm{I}}$}

\$1. The preparation of Xerxes against Greece.

\$2. Xerxes Armie entertained by Pythius: his cutting off Mount Athos from the Continent...

\$3. Of the fights at Thermopyle and Artemisium.

\$4. The attempt of Xerxes vpon Apollo's temple: and his taking of Athens.

I Xerxes' invasion of Greece may appear to be a unit independent of the rest of the History; but the final section (pp. 23I f.) places the account within Ralegh's comprehensive design. Cf. above, p. 32. 